\title{
Lise Öğrencilerinde Siber Zorbalıkla Başa Çıkmanın Yordayıcısı Olarak İyimserlik-Kötümserlik*
}

\section{İhsan AKEREN \\ Erzincan Binali Yıldırım Üniversitesi, Tercan Meslek Yüksekokulu}

\section{Öz}

$\mathrm{Bu}$ araştırmada ergenlerin sahip oldukları iyimserlik ve kötümserlik düzeyinin onların siber zorbalıkla başa çıkma becerilerini ne düzeyde yordadığı incelenmiştir. $\mathrm{Bu}$ doğrultuda araştırma ilişkisel tarama araştırması olarak planlanmıştır. Araştırmaya Erzincan'da öğrenim gören 375 lise öğrencisi katılmıştır. Ergenlerin iyimserlik-kötümserlik düzeylerini ölçmek amacıyla Ergenlerde İyimserlik-Kötümserlik Ölçeği, siber zorbalıkla başa çıkma düzeylerini ölçmek amacıyla Ergenlere Yönelik Siber Zorbalıkla Başa Çıkma Ölçeği kullanılmıştır. Araştırma sonucunda, iyimserlik düzeyinin siber zorbalıkla başa çıkmanın tüm alt boyutlarını yordadığı, kötümserlik düzeyinin siber zorbalıkla başa çıkmanın sosyal destek arama ve yardım arama boyutlarını yordadığı, mücadele etme ve çevrimiçi güvenlik alt boyutlarını ise yordamadığı ortaya çıkmıştır. Ergenlerin iyimserlik düzeyindeki artısın onların siber zorbalıkla başa çıkma becerilerini artırdığı, kötümserlik düzeyindeki artışın sosyal destek arama ve yardım arama becerilerini azalttığı, mücadele etme ve çevrimiçi güvenlik becerilerini ise etkilemediği tespit edilmiştir. İyimserliğin siber zorbalıkla başa çımada destekleyici bir kişisel kaynak olduğu ve kötümserliğin siber zorbalığa maruz kalma riskini artırdığı sonucuna varılabilir.

Anahtar Kelimeler: İyimserlik, kötümserlik, siber zorbalıkla başa çıkma, lise öğrencileri, yordama

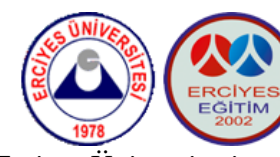

Erciyes Üniversitesi, Eğitim Fakültesi,

Kayseri/TÜRKIYYE

Erciyes Journal of

Education (EJE)

DOI: 10.32433/eje.807426

\section{SCREENED BY}

\section{iThenticate}

Tür: Araştırma

Makale Geçmişi

Gönderim : $\quad 08.10 .2020$

Kabul : $\quad 21.01 .2021$

Yayınlanma : 28.05.2021

Önerilen Atıf

Akeren, İ. (2021). Lise öğrencilerinde siber zorbalıkla başa çıkmanın yordayıcısı olarak iyimserlik-kötümserlik. Erciyes Journal of Education, 5(1), 87-104. https://doi.org/10.32433/eje.807426

1. Öğretim Görevlisi, Sosyal Hizmetler, iakeren@erzincan.edu.tr, https://orcid.org/0000-0001-5615-4189 


\title{
Optimism-Pessimism as a Predictor of Coping Cyberbullying in High School Students*
}

\author{
İhsan AKEREN \\ Erzincan Binali Yildırım University, Tercan Vocational School
}

\begin{abstract}
The aim of the study was to examine to what extent adolescents' level of optimism and pessimism predicted their ability to cope with cyberbullying. For this purpose, the research was planned as a relational cross-hatching model. The study was carried out with 375 high school students studying in Erzincan. The data was collected using "Optimism-Pessimism Scale in Adolescents" which was implemented to determine the optimism-pessimism levels of adolescents and "the Scale on Coping with Cyber Bullying towards Adolescents" which was used to measure their level of coping with cyberbullying. The study reveals that the level of optimism predicts all sub-dimensions of coping with cyberbullying, while the level of pessimism predicts the social support seeking and help-seeking dimensions of coping with cyberbullying, it does not predict the sub-dimensions of fighting and online security. According to the findings of this study, the increase in the level of optimism of adolescents enhances their coping skills with cyberbullying, although the increase in the level of pessimism decreases their social support seeking and help-seeking skills, and does not affect their ability to struggle and online security. On the basis of these results it may be concluded that optimism is a supportive personal resource in dealing with cyberbullying and pessimism increases the risk of being exposed to cyberbullying.
\end{abstract}

Keywords: Optimism, pessimism, cyberbullying, high school students, regression

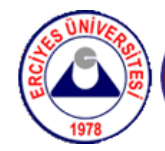

Erciyes Faculty of Education, Kayseri/TURKEY

Erciyes Journal of

Education (EJE)

DOI: $10.32433 /$ eje. 807426

SCREENED BY

\section{iThenticate}

Type: Research

Article History

Received : 08.10.2020

Accepted : 21.01.2021

Published : 28.05.2021 


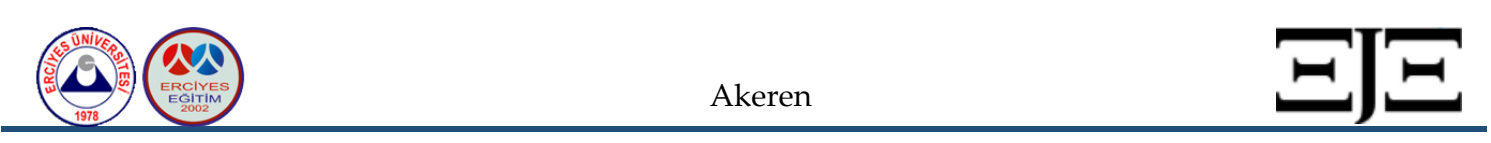

Erciyes Journal of Education 2021, Vol 5, No 1, 87-104

\section{EXTENDED ABSTRACT}

\section{Introduction}

For several years, the use of information and communication technologies is a necessity, and conflicts are inevitable with communication. It is obvious that some of the conflicts cause cyberbullying. Cyberbullying shows a repetitive feature that occurs with the malicious use of information technologies (Belsey, 2007) and aims to harm the other person (Akbaba \& Eroğlu, 2013). It is noteworthy that cyberbullying has very devastating effects, especially on the victims.

Reducing the above-mentioned negative effects of cyberbullying on adolescents is important for their healthy development; However, it is also known that awareness studies have positive effects on preventing the emergence of cyberbullying. This approach, which has a proactive perspective, aims to prevent cyberbullying from ever happening. Because avoiding the occurrence of the problem from the beginning is more effective than reducing its effects after the problem occurs.

Despite all the programs and efforts to prevent the occurrence of cyberbullying, students can become victims of this behavior. This underlines the importance of how students struggle with the bullying they are exposed to. Determining which personal characteristics are effective in combating cyberbullying at what level requires the investigation of these characteristics of students. Positive psychology is one of the areas that come to mind in this regard.

Positive psychology is a field that includes preventive studies that enable the individual to embrace life throughout his life, carry his life to a better point, and improve the skills and capacities of the individual, different from working with pathology (Peterson, 2000; Reschly \& Ysseldyke, 1999, cited in Eryllmaz, 2013).

Optimism is an individual's expectation that everything will go well in his life despite all the difficulties he faces (Goleman, 2016). Pessimism, in contrast to optimism, is when individuals have anticipation that bad things will happen to them. Considering these explained characteristics of optimism, it can be a resource for students to cope with cyberbullying; pessimism is thought to be an obstacle.

\section{Purpose}

Cyberbullying is a negative stimulus, a form of aggression, that adolescents are densely exposed to today. This form of aggression affects adolescents negatively in many ways. It can also affect the life of every adolescents in a wide spectrum, such as their academic performances, criminal behaviors, substance abuses, suicide attempts. Protecting adolescents from the harms of cyberbullying depends on eliminating the obstacles to their well-being, academic success and positive development. Students' level of optimism is a resource for overcoming the destructive effects of cyberbullying; the fact that pessimism levels constitute a risk factor in increasing the damage caused by cyberbullying reveals the importance of the research. Accordingly, the present study aims to determine the optimism-pessimism levels of adolescents and to reveal the extent to which these variables predict cyberbullying behavior. Determining this relationship will 
enable students to be aware of the risk factors they need to control, as well as the resources they can use to combat cyberbullying.

\section{Method}

In this study, quantitative research method and survey research design was used. Survey research is a research design in which the effect of independent variables or variables on one or more dependent variables is tried to be determined (Gürbüz \& Şahin, 2017).

The participants in this study comprised 375 high school students studying in Erzincan. While determining the sample, one of the non-random sampling methods, the convenience sampling method was preferred in order to reach a large number of people. Optimism-Pessimism Scale in Adolescents was implemented to measure the levels of optimism and pessimism, and "the Scale on Coping Cyber Bullying towards Adolescents" was used to measure their level of coping with cyberbullying.

\section{Findings}

The findings reveal that the level of optimism predicts all dimensions of coping with cyberbullying, the level of pessimism predicts the social support seeking and help seeking dimensions of coping with cyberbullying, but does not predict the sub-dimensions of fighting and online security. From the results obtained, while the increase in the level of optimism of adolescents increases their coping skills with cyberbullying, the increase in the level of pessimism decreases their social support seeking and help-seeking skills, and does not affect their ability to struggle and online security.

\section{Discussion E Conclusion}

The finding that optimism is effective in dealing with cyberbullying is consistent with previous research findings. When considered as a personality trait, optimism is the degree to which an individual has a general positive expectation. Individuals with a high level of optimism also have high subjective well-being. These people deal with big obstacles, they show less avoidance and give up behavior when faced with obstacles. In addition, it is seen that the social relations of optimistic individuals are more successful than the pessimists (Carver et al, 2010). Because of these features, optimistic individuals can successfully use effective coping strategies against bullying, which is a form of conflict. As a matter of fact, it is reported that the level of optimism of secondary school students who do not participate in bullying is higher than bullies and victims (Totan \& Tabakç1, 2010). Likewise, Betts et al. (2019) report that the risk of optimism among adolescents, young adults and adults being victims of cyberbullying is low.

Pessimism significantly reduced the behaviors of seeking social support and seeking help in dealing with cyberbullying; does not affect combat and online safety behavior; in general pessimism partially predicts coping with cyberbullying. In the literature review, there was no research finding that would directly compare this finding. Less research on the effect of pessimism on dealing with cyberbullying suggests that this variable is indirectly investigated through optimism. Pessimistic individuals are unwilling to face difficulties, have an avoidant attitude and are unsuccessful in overcoming them, and they have limited social resources to apply around them. Pessimistic people have low self-esteem and are suspicious of their abilities (Carver et al., 2010). These features prevent them from seeking social support and seeking help 
in dealing with cyberbullying. The fact that pessimism has no effect on fighting against cyberbullying and on online security can be explained by the reluctance-inertia due to the characteristics of these students. On the other hand, Carver et al. (2010) state that pessimists are less than optimists in the society, and we have less information about pessimists than optimists. This explanation gives us an idea why pessimism is weaker than optimism in explaining how to deal with cyberbullying. Meland et al. (2010), in their research on bullies and victims between the ages of 11-15, concluded that bullies and victims reported more emotional disorders, physical complaints, lack of self-confidence and pessimism compared to students who were not related to bullying. Similarly, it is stated that victims of bullying feel lonely and worse (Nansel et al., 2001).

It may be suggested that school guidance services including activities and practices can increase students' optimism levels in cyberbullying programs. In addition, it can be said that students who are victims of cyberbullying have low levels of optimism and high levels of pessimism. For this reason, it is beneficial to take these variables into account in order to overcome the victimization of these students. It should be considered that students with high levels of pessimism are at risk of cyberbullying.

\section{Gíniş}

İnsanoğlunun içinde yaşamış olduğu 21. yüzyıl pek çok teknolojik ilerlemeye ve kolaylığı sunacak gelişmelere tanıklık etmektedir. Sanayileşme ve seri üretimle birlikte özellikle bilgi ve iletişim teknolojilerinin son yıllardaki atılımıyla dünyanın avucumuzun içine sığdığı, iletişimin günün her saatinde mümkün olduğu, etkileşimin insanlar için bir gereklilik olduğu görülmektedir. Oluşturulan bu siber dünyanın sağlamış olduğu pek çok kolaylıkla birlikte getirdiği pek çok risk bulunmaktadır. Bu riskler son yıllarda çok sayıda araştırmanın konusu olmuştur. Bilgiye ulaşımın kolaylığının yanında kişisel bilgilerimizin çalınması da kolaylaşmaktadır. Diğer insanlarla sanal etkileşime girdiğimizde yapmış olduğumuz bir paylaşımın aleyhimize kullanılması tehlikesi de vardır. Bireylerin saklamış oldukları pek çok dijital verinin (parola, fotoğraf, video vb.) kötü niyetli kişilerin eline geçmesiyle şantaja maruz kalmaları verilerinin izinleri dışında ifşa edilmesine hemen her gün tanık olunmaktadır. Sanal ortam günümüz ergenlerinin başta sosyal medya olmak üzere sürekli içinde bulundukları bir dünya hâline gelmiştir. Öyle ki bu ortamlar ergenler açısından içinde bulundukları gerçek dünyadan daha öncelikli algılanabilmektedir. Örneğin ergenlerin sosyal medya hesabındaki takipçi ya da beğeni sayısı, kendilerine yönelik öznel değerlendirmelerinde gerçek yaşamlarında kaç arkadaşa sahip olduklarından, kaç kişiden takdir aldıklarından daha belirleyici olabilmektedir.

Günümüzde bilgi ve iletişim teknolojileri kullanımının gereklilik olduğu ortadadır. Bu gereklilik kapsamında insanlar sanal iletişimde bir araya geldiklerinde çeşitli çatışmalar yaşamaktadır. Yaşanılan çatışmaların bir kısmının siber zorbalığa neden olduğu bilinmektedir. Zorbalık, belirli bir zaman dilimi içerisinde, sürekli şekilde, kendini savunamayan birisine yönelik gerçekleştirilen kasıtlı saldırgan davranıştır (Smith vd., 2008). Siber zorbalık ise fiziksel/akran zorbalığının internete taşınmasıyla ortaya çıkar. Siber zorbalık, bilişim teknolojilerinin kötü amaçlı kullanımıyla ortaya çıkan (Belsey, 2007) ve karşıdaki kişiye zarar verme amacını taşıyan (Akbaba ve Eroğlu, 2013) tekrarlı bir özellik göstermektedir. Alanyazında siber zorbalığın özellikle mağdurlar açısından oldukça yıkıcı etkilerinin olduğuna dikkat çekilmektedir. Bu 
etkilerden bazıları düşük ders başarısı (Beran ve Li, 2005), suç davranışı, madde kötüye kullanımı ve depresyon (Mitchell vd., 2007), stres (Wolak vd., 2006), intihar etme düşüncesi (Akbıyık ve Kestel, 2016) hatta intihardır (Edwards vd., 2016).

Siber zorbalığın ergenler üzerindeki yukarıda belirtilen olumsuz etkilerinin azaltılması onların sağlıklı gelişime sahip olmaları açısından önem arz etmektedir ancak daha etkilisinin siber zorbalığın ortaya çıkmasını önleyecek farkındalık çalışmaları yürütmek olduğu da bilinmektedir. Proaktif bir bakış açısına sahip olan bu yaklaşım, siber zorbalığın aslında hiç yaşanmamasını amaçlamaktadır. Çünkü sorunun ortaya çıkmasının baştan önlenmesi, sorun ortaya çıktıktan sonra etkilerinin azaltılmasından daha etkili olmaktadır. Bu amaçla siber zorbalığın önlenmesine yönelik bazı programlar geliştirilmiştir. Siber zorbalığın önlenmesine yönelik en kapsamlı programı geliştirenlerden Olweus, Sweden, Smith, Morita, Junger-Tas, Olweus, Catalano ve Slee (1999), zorbalıkla ilgili farkındalık oluşturmanın, öğrencileri bu konuda bilgilendirmenin, zorbalığa engel olacak kuralları açık biçimde belirtmenin, kuralların ihlal edilmesi hâlinde ortaya çıkacak olumsuz sonuçların ortaya konmasının ve öğrencilere olumlu rol model olmanın önemine vurgu yapmaktadır. Aynı şekilde Willard (2005) da siber zorbalığı önlemede bu tür önleme programlarının örnek alınarak çeşitli müdahale programları geliştirilebileceğini savunmaktadır (akt. Koç vd., 2016).

Siber zorbalığın ortaya çıkmasının önlenmesine yönelik tüm programlara ve çabalara rağmen öğrenciler bu davranışın mağduru olabilmektedirler. Bu durumda öğrencilerin maruz kaldığı zorbalıkla ne şekilde mücadele ettiklerinin önemi artmaktadır. Siber zorbalıkla mücadele etmede öğrencilerin sahip oldukları öznel faktörlerin etkililiği araştırmalara konu olmuştur. OlenikShemesh ve Heiman $(2014,2017)$, öğrencilerin sosyal destek ve öz yeterlilik algılarının, öznel iyi olma düzeylerinin düştükçe, yalnızlık duygularının arttıkça siber mağduriyet algılarının arttığını, benzer şekilde düşük beden imajının yüksek siber mağduriyetle ilişkili olduğunu belirtmektedirler. Völlink vd. (2013), problem çözme becerisi yüksek olan öğrencilerin siber zorbalıkla baş etmede başarılı olduklarını, Kokkinos vd. (2014), siber zorba ve mağdurların psikopatolojik puanlarının zorba veya mağdur olmayanlara göre daha yüksek olduğunu ortaya koymuşlardır. Siber zorbalıkla mücadelede farklı kişisel özelliklerin etkililik düzeylerinin belirlenmesi, öğrencilerin söz konusu özelliklerinin araştırılmasını gerektirmektedir. Bu konuda pozitif psikoloji sahip olduğu kavramlarla öne çıkan alanlardan biridir.

Pozitif psikoloji, bireyin yaşamı boyunca hayata sarılmasını, hayatını daha iyi bir noktaya taşımasını sağlayan, patoloji odaklı çalışmaktan farklı olarak bireyin becerilerini ve kapasitelerini geliştiren önleyici çalışmaları kapsayan bir alandır (Peterson, 2000; Reschly ve Ysseldyke, 1999, aktaran Eryılmaz, 2013). Pozitif psikoloji iyimserlik, öz saygı, mutluluk, öznel iyi oluş gibi olumlu kavramları içerir. Özellikle iyimserliğin bireylerin ruhsal ve fiziksel sağliklarına olumlu katkı yaptığı belirtilmektedir (Temel vd., 2007). İyimserlik, bireyin karşılaştığı tüm güçlüklere rağmen hayatında her şeyin iyi gideceğine yönelik beklentisidir (Goleman, 2016). Bu kişiler zorlukları önemsemeyen ve her türlü zorluğa kolaylıkla karşı koyabilen, özgüven sahibi, diğer insanlarla kolaylıkla dostluk kurabilen özelliklere sahiptirler (Kutlu vd, 2004). Peterson (2000), zorlu durumlarla başa çıkabilmelerini sağlamak için iyimserliğin bireylere öğretilmesi gerektiğini belirtmektedir. Kötümserlik ise iyimserliğin zıddı olarak bireylerin başlarına kötü şeyler geleceğiyle ilgili beklentiye sahip olmalarıdır. Kötümser bireyler iyimserlere göre daha kadercidir, bir şeyleri değiştiremeyeceklerine inanırlar, daha çabuk pes ederler ve bu nedenle depresyona daha fazla girmektedirler (Carver vd., 2010; Scherer vd., 2001; Seligman, 2007). Bu 
özellikler göz önüne alındığında, iyimserliğin siber zorbalıkla başa çıkmada öğrenciler için kaynak teşkil edebileceği, kötümserliğin ise engel teşkil edebileceği düşünülmektedir.

\section{Araştırmanın Önemi ve Amacı}

Siber zorbalık günümüzde ergenlerin yoğunlukla maruz kaldığı bir saldırganlık biçimidir. Bu saldırganlık biçimi ergenleri pek çok şekilde olumsuz yönde etkilemektedir. Öyle ki bu etki ergenlerin ders başarılarının olumsuz etkilenmesinden suç davranışına, madde kötüye kullanımından intiharına kadar geniş bir yelpazede gözlenmektedir (Beran ve Li, 2005; Edwards vd, 2016; Akbıyık ve Kestel, 2016; Mitchell vd, 2007; Wolak vd., 2006). Ergenlerin siber zorbalığın zararlarından korunması, onların iyilik hâli, ders başarısı ve olumlu yönde gelişime sahip olmalarının önündeki engellerin bertaraf edilmesine bağlıdır. Öğrencilerin sahip oldukları iyimserlik düzeylerinin siber zorbalığın yıkıcı etkilerinin üstesinden gelinmesinde kaynak oluşturması, kötümserlik düzeylerinin ise siber zorbalığın vereceği zararın artmasında risk unsuru oluşturması araştırmanın önemini ortaya koymaktadır. Bu doğrultuda mevcut araştırmada ergenlerin sahip oldukları iyimserlik-kötümserlik düzeylerinin ve siber zorbalıkla başa çıkma düzeylerinin belirlenmesi, her iki değişken arasındaki ilişki düzeyinin belirlenmesi ve iyimserlik-kötümserliğin siber zorbalıkla mücadele etme davranışını ne düzeyde yordadığının ortaya konması amaçlanmaktadır. Bu ilişkinin belirlenmesi, öğrencilerin siber zorbalıkla mücadelede başvurabilecekleri kaynakların yanı sıra kontrol altına almaları gereken risk faktörlerinin de farkında olmalarını sağlayacaktır. Pozitif psikoloji en genel tanımılla iyi yaşamın ne olduğu, ruh sağlığı yerinde olan insanın kim olduğu sorularına yanıt arayan bir yaklaşımdır. $\mathrm{Bu}$ yaklaşımda, bu doğrultuda psikolojik yönden sağlıklı bireylerin ne gibi özelliklere sahip olmaları gerektiği yönünde çeşitli tezler ileri sürmüştür (Keldal, 2015). Ayrıca pozitif psikoloji çoğu insanın tüm zorluklara karşın erdemli, amaç dolu bir hayat yaşamayı nasıl başardığını da açılamaya çalışmaktadır (Sheldon ve King, 2001). Bu doğrultuda bireyin güçlü yönü olan olumlu kişilik özelliklerine odaklanmaktadır. İyimserlik de bireyin sahip olduğu olumlu bir kişilik özelliği olarak yaşamında karşılaştığı ve karşılaşabileceği sorunların üstesinden gelmesinde ona kaynak sağlayacaktır. Siber zorbalığın bireyin karşılaşabileceği sorunlardan biri olduğu göz önüne alındığında pozitif psikolojinin bir kavramı olan iyimserliğin bu sorunla başa çımada etkililiğinin ortaya konması bu araştırmanın önemini ortaya koymaktadır.

\section{YÖNTEM}

\section{Araştırma Deseni}

Bu araştırmada yöntem olarak nicel araştırma yöntemi, desen olarak tarama araştırmalarından ilişkisel tarama deseni kullanılmıştır. İlişkisel tarama araştırması, iki veya daha fazla değişken arasındaki ilişkinin varlığının ve derecesinin belirlenmeye çalışıldığı araştırma desenidir (Fraenkel ve Wallen, 1993). Bu araştırmada lise öğrencilerinin iyimserlik-kötümserlik düzeyleri ile siber zorbalıkla başa çıkma becerileri arasındaki ilişkinin ortaya konması amaçlandığından ilişkisel desen kullanılmıştır. Bu amaçla aşağıdaki araştırma sorularının yanıtı aranmaktadır:

1. Lise öğrencilerinin iyimserlik-kötümserlikleri ile siber zorbalıkla başa çıkma becerileri ne düzeydedir?

2. İyimserlik-kötümserlik ile siber zorbalıkla başa çıkma becerileri arasında bir ilişki var midir? 
3. İyimserlik-kötümserlik düzeyi siber zorbalıkla başa çıkma becerilerini yordamakta midir?

\section{Çalışma Grubu}

Mevcut araştırmada katılımcılar Erzincan ili Tercan ilçesinde bulunan orta öğretim kurumlarında 2019-2020 eğitim öğretim yılı içerisinde öğrenim gören 375 lise öğrencisinden oluşmaktadır. Çalışma grubu oluşturulurken çok sayıda kişiye en hızlı biçimde ulaşabilmek amacıyla rastlantısal olmayan örnekleme yöntemlerinden kolay ulaşılabilir durum örneklemesi tercih edilmiştir. Kolay ulaşılabilir durum örneklemesi, ulaşma, maliyet ve zaman gibi kaynakların kısıtlılığı nedeniyle kişilerin örnekleme dâhil edilmesidir (Gürbüz ve Şahin, 2017). Bu çalışmada ihtiyaç duyulan yeterli katılımcıya ulaşılması amaçlandığı için kolay ulaşılabilir durum örneklemesi tercih edilmiştir. Çalışma kapsamında araştırma yapılan alanda bulunan tüm ortaöğretim kurumlarına ulaşılarak 375 öğrencinin tamamı örnekleme dâhil edilmiştir. Çalışma grubundaki bireylerin özellikleri Tablo 1'de sunulmuştur.

Tablo 1. Araşttrmaya dâhil edilen ergenlerin demografik özellikleri

\begin{tabular}{lcc}
\hline Demografik değişkenler & N & \% \\
\hline Kiz & 170 & 45.3 \\
\hline Erkek & 205 & 54.7 \\
\hline Toplam & 375 & $\mathbf{1 0 0}$ \\
\hline 9. sinif & 100 & 26.7 \\
\hline 10. sinıf & 98 & 26.1 \\
\hline 11. sinıf & 84 & 22.4 \\
\hline 12. sinıf & 93 & 24.8 \\
\hline Toplam & $\mathbf{3 7 5}$ & $\mathbf{1 0 0}$ \\
\hline
\end{tabular}

Tablo 1'de sunulduğu üzere araştırmaya katılan öğrencilerin 170'i kız (\% 45,3), 205'i erkek (\% 54,7), 100'ü 9. sinıf (\% 26,7), 98'i 10. sinıf (\% 26,1), 84'ü 11. sinıf (\% 22,4), 93'ü ise 12. sinıftır (\%24,8).

\section{Veri Toplama Araçları}

Araştırmada ergenlerin iyimserlik-kötümserlik düzeylerini ölçmek amacıyla "Ergenlerde İyimserlik-Kötümserlik Ölçeği", siber zorbalıkla başa çıkma düzeylerini ölçmek amacıyla "Ergenlere Yönelik Siber Zorbalıkla Başa Çıkma Ölçeği" ve sosyo-demografik bilgi formu kullanılmıştır.

Ergenlerde İyimserlik-Kötümserlik Ölçeği: Ölçek Çalışkan ve Uzunkol (2018) tarafından 11-16 yaşındaki ergenlerin iyimserlik ve kötümserlik düzeylerini belirlemek amacıyla geliştirilmiştir. $\mathrm{Bu}$ amaçla 30 öğrenciyle ön uygulama yapılarak likert tipinde (5'li) 30 maddelik havuz oluşturulmuş, ardından geçerlik ve güvenirlik çalışmaları daha büyük öğrenci grubuyla yapılarak toplam varyansın \% 43.24'ünü açıklayan iki faktörlü (iyimserlik ve kötümserlik) 16 maddelik bir yapı elde edilmiştir. Ölçekten alınabilecek en düşük puan 16; en yüksek puan 80' dir. Ölçeğin Cronbach Alpha güvenirlik katsayısı iyimserlik boyutu için .86; kötümserlik boyutu için .82 hesaplanmıştır. Yapılan Doğrulayıcı Faktör Analizi sonuçlarına göre Ki-kare/serbestlik derecesinin $\left(X^{2}=228.63, \mathrm{sd}=103 ; X^{2} / \mathrm{sd}=2.22<3 ; \mathrm{p}=.00\right) 3^{\prime}$ ten küçük olduğu, RMSEA değerinin .05 olduğu görülmüştür. Diğer uyum indeksleri SRMR .04, GFI .94, AGFI .93, NNFI .98, NFI .97 RFI .96, CFI .98, IFI .98 olarak hesaplanmıştır. Sonuç olarak analizlerin ortaya koymuş olduğu 
Erciyes Journal of Education 2021, Vol 5, No 1, 87-104

bulgulara göre 16 madde ve iki boyuttan oluşan ölçeğin ergenlerde iyimserlik-kötümserliği ölçmede geçerli ve güvenilir olduğu kanıtlanmıştır (Çalışkan ve Uzunkol, 2018).

Mevcut araştırmada ise Ki-kare/serbestlik derecesinin $\left(X^{2}=308.36, \mathrm{sd}=103 ; X^{2} / \mathrm{sd}=2.99<3 ; \mathrm{p}=.00\right)$ $3^{\prime}$ ten küçük olduğu, RMSEA değerinin .73 olduğu görülmüştür. Diğer uyum indeksleri SRMR .58, GFI .91, NNFI .96, NFI .94 RFI .93, CFI .96, IFI .96 olarak hesaplanmıştır. Yapılan DFA bulgularına göre ölçeğin iki boyutlu yapısının doğrulandığı görülmektedir (Çalışkan ve Uzunkol, 2018).

Ergenlere Yönelik Siber Zorbalıkla Başa Çıkma Ölçeği: Ölçek Peker, Özhan ve Eroğlu (2015) tarafından ergenlerin siber zorbalıkla başa çıkma davranışlarını ölçmek amacıyla geliştirilmiştir. Sosyal destek arama, yardım arama, mücadele etme ve çevrimiçi güvenlik alt boyutlarından oluşmaktadır. Ölçekten alınabilecek en düşük ve en yüksek puanlar sosyal destek arama boyutu için 3-12, yardım arama boyutu için 5-20, mücadele etme boyutu için 4-16, çevrimiçi güvenlik boyutu için 5-20'dir. 318 lise öğrencisi üzerinde yapılan uygulama sonuçlarına göre ölçeğin açımlayıcı faktör analizi, toplam varyansın \% 61,36'sını açılayan 17 maddelik ve 4 faktörlük bir yapı ortaya koymuştur. Ölçeğin Cronbach Alpha iç tutarlılık katsayılarının alt boyutlar için, 70,86; iki yarı test güvenirliğinin alt boyutlar için ,66-,86; test tekrar test güvenirliğinin alt boyutlar için ,68-,83 arasında değiştiği bildirilmektedir. Yapılan Doğrulayıcı Faktör Analizi sonuçlarına göre Ki-kare/serbestlik derecesinin $\left(X^{2}=247.92, \mathrm{sd}=111 ; X^{2} / \mathrm{sd}=2.23<3 ; \mathrm{p}=.00\right)$ 3'ten küçük olduğu, RMSEA değerinin .062 olduğu görülmüştür. Diğer uyum indeksleri SRMR .060, GFI .92, NNFI .95, NFI .93, CFI .96, IFI .96 olarak hesaplanmıştır. Sonuç olarak analizlerin ortaya koymuş olduğu bulgulara göre 17 madde ve dört boyuttan oluşan ölçeğin ergenlerde siber zorbalıkla başa çıkmayı ölçmede geçerli ve güvenilir olduğu kanıtlanmıştır (Peker, Özhan ve Eroğlu, 2015).

Mevcut araştırmada ise Ki-kare/serbestlik derecesinin $\left(X^{2}=295.14, \mathrm{sd}=113 ; X^{2} / \mathrm{sd}=2.61<3 ; \mathrm{p}=.00\right)$ $3^{\prime}$ ten küçük olduğu, RMSEA değerinin .66 olduğu görülmüştür. Diğer uyum indeksleri SRMR .52, GFI .92, NNFI .94, NFI .93 RFI .91, CFI .95, IFI .95 olarak hesaplanmıştır. Yapılan DFA bulgularına göre ölçeğin dört boyutlu yapısının doğrulandığı görülmektedir (Peker, Özhan ve Eroğlu, 2015).

Sosyo-Demografik Bilgi Formu: Form, araştırmaya katılan öğrencilerin cinsiyetleri ve sınıf seviyeleriyle ilgili bilgi almak amacıyla araştırmacı tarafından oluşturulmuştur.

\section{Verilerin Analizi}

Araştırmada verilerin analizinde SPSS Paket Programı 22.0 kullanılmış, anlamlılık düzeyi $p<.05$ olarak belirlenmiştir. Veriler analize dâhil edilmeden önce normal dağılıma sahip olup olmadıklarını belirlemek için öncelikle çarpıklık ve basıklık analizi yapılmıştır. İlgili analizin sonuçları Tablo 2' de sunulmuştur.

Tablo 2. Iyimserlik-kötümserlik ve siber zorbalıkla başa çıma ölçeği alt boyutlarma ilişkin basıklık ve çarpıklık değerleri

\begin{tabular}{llcccc}
\hline \multirow{2}{*}{ Ölçek } & \multirow{2}{*}{ Değişkenler } & \multicolumn{2}{c}{ Çarpıklık } & \multicolumn{2}{c}{ Basılklık } \\
\cline { 3 - 6 } & & \multicolumn{3}{c}{ S. H. } & S. H. \\
\hline \multirow{2}{*}{ EIKÖ } & İyimserlik & -.65 & .13 & -.02 & .25 \\
\cline { 2 - 6 } & Kötümserlik & .45 & .13 & -.09 & .25 \\
\hline
\end{tabular}


Erciyes Journal of Education 2021, Vol 5, No 1, 87-104

\begin{tabular}{llllll}
\hline & Sosyal destek arama & -.34 & .13 & -.54 & .25 \\
\cline { 2 - 6 } SZBÇÖ & Yardım arama & .09 & .13 & -.79 & .25 \\
\cline { 2 - 6 } & Mücadele etme & -.34 & .13 & -.51 & .25 \\
\cline { 2 - 6 } & Çevrimiçi güvenlik & -.70 & .13 & .07 & .25 \\
\hline
\end{tabular}

Tablo 2'de iyimserlik-kötümserlik değişkeni ile siber zorbalıkla başa çıkma değişkenine ait alt boyutların çarpıklık değerlerinin -.70 ile .45 arasında değiştiği; basıklık değerlerinin ise -.79 ile .07 arasında değiştiği görülmektedir. Bu doğrultuda ilgili değerler -1.5 ile +1.5 arasında olması dağılımın normalden aşırı şekilde sapmadığını göstermektedir. Bu nedenle ilgili alt boyutların dağılımlarının normal olduğu kabul edilmektedir (Tabachnick vd., 2007). Dağılımın normalliği verilerin parametrik analize dâhil edilmesinde bir gereklilik olarak görülmektedir.

Araştırmada ergenlerin iyimserlik-kötümserlik puanları ile siber zorbalıkla başa çıkma puanları arasındaki ilişkinin ortaya konması amacıyla veriler Pearson korelasyon analizine dahil edilmiştir. İyimserlik-kötümserlik ile siber zorbalıkla başa çıkmanın alt boyutları arasındaki nedensel ilişkinin ortaya konması için basit doğrusal regresyon analizi kullanılmıştır.

\section{BULGULAR}

Öğrencilerin iyimserlik-kötümserlik ve siber zorbalıkla başa çıkma puanlarının ne düzeyde olduğunun belirlenmesi amacıyla betimsel istatistik yapılmış, sonuçlar Tablo 3'te sunulmuştur.

Tablo 3. İyimserlik-kötümserlik ve siber zorbalıkla başa çıkma alt boyutlarına ilişkin betimsel istatistikler

\begin{tabular}{llcccc}
\hline \multirow{2}{*}{ Ölçek } & \multirow{2}{*}{ Değişkenler } & Ortalama & Ortanca & Mod & S.S. \\
\cline { 3 - 6 } & & & & & \\
\hline \multirow{2}{*}{ EIKÖO } & İyimserlik & 28.29 & 29.00 & 30.00 & 7.25 \\
\cline { 2 - 6 } & Kötümserlik & 21.10 & 21.00 & 22.00 & 6.85 \\
\hline \multirow{3}{*}{ SZBÇÖ } & Sosyal destek arama & 8.34 & 9.00 & 9.00 & 2.33 \\
\cline { 2 - 6 } & Yardım arama & 11.65 & 12.00 & 11.00 & 4.02 \\
\cline { 2 - 6 } & Mücadele etme & 11.34 & 11.00 & 11.00 & 3.10 \\
\cline { 2 - 6 } & Çevrimiçi güvenlik & 15.10 & 16.00 & 20.00 & 3.68 \\
\hline
\end{tabular}

Öğrencilerin iyimserlik-kötümserlik düzeyleri ile siber zorbalıkla başa çıkma davranışının alt boyutları olan sosyal destek arama, yardım arama, mücadele etme ve çevrimiçi güvenlik alt boyutları arasındaki ilişkileri incelemek için Pearson korelasyon analizi yapılmıştır. Analiz bulguları Tablo $4^{\prime}$ te sunulmuştur.

Tablo 4. İyimserlik-kötümserlik değişkenleri ile siber zorbalıkla başa çıkma alt boyutlarına ilişkin Pearson korelasyon değerleri

\begin{tabular}{lcccc}
\hline İyimserlik- & & & & \\
Kötümserlik & Sosyal destek arama & Yardım arama & Mücadele etme & Çevr. Güv. \\
\hline İyimserlik & $.30^{* *}$ & $.28^{* *}$ & $.18^{* *}$ & $.27^{* *}$ \\
\hline
\end{tabular}


Erciyes Journal of Education 2021, Vol 5, No 1, 87-104

\begin{tabular}{lcccc}
\hline $\mathrm{p}$ & .00 & .00 & .00 & .00 \\
\hline Kötümserlik & $-.23^{*}$ & $-.18^{* *}$ & .02 & -.10 \\
\hline $\mathrm{p} \quad$ & .02 & .00 & .64 & .06 \\
\hline${ }^{*} \mathrm{p}<.05 \quad{ }^{* *} \mathrm{p}<.01$ & & & &
\end{tabular}

Tablo 4 incelendiğinde iyimserlik ile siber zorbalıkla başa çıkmanın tüm alt boyutları arasında pozitif yönde zayıf ilişki olduğu, kötümserlik ile sosyal destek arama ve yardım arama arasında negatif yönde çok zayıf anlamlı ilişkiler olduğu görülmektedir. Öte yandan kötümserlik ile mücadele etme ve çevrimiçi güvenlik arasında herhangi bir anlamlı ilişki olmadığı görülmektedir.

İyimserliğin ve kötümserliğin ergenlerin sosyal destek arama davranışlarını ne düzeyde yordadığını belirlemek için basit doğrusal regresyon analizi yapılmış, sonuçlar Tablo 5 'te ve Tablo 6'da sunulmuştur.

Tablo 5. İimserliğin sosyal destek arama alt boyutunu yordamasına ilişkin basit doğrusal regresyon analizi sonuçları

\begin{tabular}{llccccc}
\hline & \multicolumn{2}{c}{ Standardize Edilmemiş Katsayı } & Standardize Edilmiş Katsayı & & \\
\cline { 2 - 6 } Model & $\mathrm{B}$ & Std. Hata & Beta & $\mathrm{t}$ & $\mathrm{p}$ \\
\hline \multirow{2}{*}{1} & 5.62 & 0.46 & & 12.16 & .00 \\
\cline { 2 - 7 } & Sabit & .01 & .02 & .30 & 6.08 & .00 \\
\hline
\end{tabular}

$\mathrm{R}^{2}=.087, \mathrm{~F}(1-375)=36.99{ }^{*} \mathrm{p}<.01$

Tablo 5 incelendiğinde iyimserliğin sosyal destek aramanın anlamlı bir yordayıcısı olduğu görülmektedir. Sosyal destek aramayı yordayan değişkenlere ilişkin doğrusal regresyon analizi sonuçları, iyimserliğin sosyal destek arama davranışının \% 8.7'sini açıkladığını göstermektedir. Sonuç olarak sosyal destek aramanın \%8.7'sinin iyimserlikle açıklandığı söylenebilir.

Tablo 6. Kötümserliğin sosyal destek arama alt boyutunu yordamasına iliş̧kin basit doğrusal regresyon analizi sonuçları

\begin{tabular}{lcccccc}
\hline & \multicolumn{2}{c}{ Standardize Edilmemiş Katsayı } & \multicolumn{2}{c}{ Standardize Edilmiş Katsay1 } & & \\
\cline { 2 - 6 } Model & $\mathrm{B}$ & Std. Hata & Beta & $\mathrm{t}$ & $\mathrm{p}$ \\
\hline 1 Sabit & 9.22 & .39 & & 26.87 & .00 \\
\hline Kötümserlik & -.04 & .02 & -.12 & -2.39 & .02 \\
\hline $\mathrm{R}^{2}=.012, \mathrm{~F}(1-375)=5.72$ & ${ }^{*} \mathrm{p}<.05$ & & & &
\end{tabular}

Tablo 6 incelendiğinde kötümserliğin sosyal destek aramanın anlamlı bir yordayıcısı olduğu görülmektedir. Sosyal destek aramayı yordayan değişkenlere ilişkin doğrusal regresyon analizi sonuçları, kötümserliğin sosyal destek arama davranışının \% 1.2'sini açıkladı̆̆ını göstermektedir. Sonuç olarak sosyal destek aramamanın \%1.2'sinin kötümserlikle açılandığı söylenebilir.

İyimserliğin ve kötümserliğin ergenlerin yardım arama davranışlarını ne düzeyde yordadığına ilişkin basit doğrusal regresyon analizi yapılmış, sonuçlar Tablo 7' de ve Tablo 8'de sunulmuştur. 
Erciyes Journal of Education 2021, Vol 5, No 1, 87-104

Tablo 7. İyimserliğin yardım arama alt boyutunu yordamasına ilişkin basit doğrusal regresyon analizi sonuçları

\begin{tabular}{lcccccc}
\hline & \multicolumn{2}{c}{ Standardize Edilmemiş Katsayı } & \multicolumn{2}{c}{ Standardize Edilmiş Katsayı } & & \\
\cline { 2 - 4 } Model & $\mathrm{B}$ & Std. Hata & Beta & $\mathrm{t}$ & $\mathrm{p}$ \\
\hline 1 Sabit & 7.19 & .80 & & 8.96 & .00 \\
\hline İyimserlik & .16 & .03 & .28 & 5.74 & .00 \\
\hline $\mathrm{R}^{2}=.078, \mathrm{~F}(1-375)$ & $=32.97$ & ${ }^{*} \mathrm{p}<.01$ & & & &
\end{tabular}

Tablo 7 incelendiğinde iyimserliğin yardım aramanın anlamlı bir yordayıcısı olduğu görülmektedir. Yardım aramayı yordayan değişkenlere ilişkin doğrusal regresyon analizi sonuçları, iyimserliğin yardım arama davranışının \% 7.8'ini açıkladığını göstermektedir. Sonuç olarak yardım aramanın \%7.8'inin iyimserlikle açıklandığı söylenebilir.

Tablo 8. Kötümserliğin yardım arama alt boyutunu yordamasına ilişkin basit doğrusal regresyon analizi sonuçları

\begin{tabular}{llcccccc}
\hline & & \multicolumn{2}{c}{ Standardize Edilmemiş Katsayı } & Standardize Edilmiş Katsayı & & \\
\cline { 2 - 6 } Model & $\mathrm{B}$ & Std. Hata & Beta & $\mathrm{t}$ & $\mathrm{p}$ \\
\hline \multirow{2}{*}{1} & Sabit & 13.91 & .66 & & 21.02 & .00 \\
\cline { 2 - 6 } & Kötümserlik & -.11 & .03 & -.18 & -3.58 & .00 \\
\hline
\end{tabular}

$\mathrm{R}^{2}=.030, \mathrm{~F}_{(1-375)}=12.81{ }^{*} \mathrm{p}<.01$

Tablo 8 incelendiğinde kötümserliğin yardım aramanın anlamlı bir yordayıcısı olduğu görülmektedir. Yardım aramayı yordayan değişkenlere ilişkin doğrusal regresyon analizi sonuçları, kötümserliğin yardım arama davranışının \% 3'ünü açıkladığını göstermektedir. Sonuç olarak yardım aramamanın \% 3’ünün kötümserlikle açıklandığı söylenebilir.

İyimserliğin ve kötümserliğin ergenlerin mücadele etme davranışlarını ne düzeyde yordadığına ilişkin basit doğrusal regresyon analizi yapılmış, sonuçlar Tablo 9'da ve Tablo 10'da sunulmuştur.

Tablo 9. İyimserliğin mücadele etme alt boyutunu yordamasına ilişkin basit doğrusal regresyon analizi sonuçları

\begin{tabular}{|c|c|c|c|c|c|c|}
\hline \multirow{2}{*}{\multicolumn{2}{|c|}{ Model }} & \multicolumn{5}{|c|}{ Standardize Edilmemiş Katsayı Standardize Edilmiş Katsayı } \\
\hline & & B & Std. Hata & Beta & $\mathrm{t}$ & $\mathrm{p}$ \\
\hline \multirow[t]{2}{*}{1} & Sabit & 9.10 & .63 & & 14.35 & .00 \\
\hline & İyimserlik & .08 & .02 & .19 & 3.65 & .00 \\
\hline
\end{tabular}

$\mathrm{R}^{2}=.032, \mathrm{~F}_{(1-375)}=13.34{ }^{*} \mathrm{p}<.01$

Tablo 9 incelendiğinde iyimserliğin mücadele etmenin anlamlı bir yordayıcısı olduğu görülmektedir. Mücadele etmeyi yordayan değişkenlere ilişkin doğrusal regresyon analizi sonuçları, iyimserliğin mücadele etme davranışının \% 3,2'sini açıkladığını göstermektedir. Sonuç olarak mücadele etmenin \% 3,2'sinin iyimserlikle açıklandı̆̆ı söylenebilir. 
Erciyes Journal of Education 2021, Vol 5, No 1, 87-104

Tablo 10. Kötümserliğin mücadele etme alt boyutunu yordamasına ilişkin basit doğrusal regresyon analizi sonuçlar

\begin{tabular}{lcccccc}
\hline & \multicolumn{2}{l}{ Standardize Edilmemiş Katsayı } & \multicolumn{2}{c}{ Standardize Edilmiş Katsayı } & & \\
\cline { 2 - 4 } Model & $\mathrm{B}$ & Std. Hata & Beta & $\mathrm{t}$ & $\mathrm{p}$ \\
\hline 1 Sabit & 11.12 & .52 & & 21.43 & .00 \\
\hline Kötümserlik & .01 & .02 & .02 & .46 & .64 \\
\hline
\end{tabular}

$\mathrm{R}^{2}=-.002, \mathrm{~F}_{(1-375)}=.22 \quad{ }^{*} \mathrm{p}>.05$

Tablo 10 incelendiğinde kötümserliğin mücadele etmenin anlamlı bir yordayıcısı olmadı̆̆1 görülmektedir. Sonuç olarak kötümserlik mücadele etme davranışını yordamamaktadır.

İyimserliğin ve kötümserliğin ergenlerin çevrimiçi güvenlik davranışlarını ne düzeyde yordadığına ilişkin basit doğrusal regresyon analizi yapılmıs, sonuçlar Tablo 11'de ve Tablo 12' de sunulmuştur.

Tablo 11. İyimserliğin çevrimiçi güvenlik alt boyutunu yordamasına ilişkin basit doğrusal regresyon analizi sonuçları

\begin{tabular}{|c|c|c|c|c|c|}
\hline \multirow[b]{2}{*}{ Model } & \multicolumn{2}{|c|}{ Standardize Edilmemiş Katsayı } & \multirow{2}{*}{$\frac{\text { Standardize Edilmiş Katsayı }}{\text { Beta }}$} & \multirow[b]{2}{*}{$\mathrm{t}$} & \multirow[b]{2}{*}{$\mathrm{p}$} \\
\hline & B & Std. Hata & & & \\
\hline 1 Sabit & 11.19 & .74 & & 15.17 & .00 \\
\hline İyimserlik & .14 & .03 & 0.27 & 5.44 & .00 \\
\hline
\end{tabular}

Tablo 11 incelendiğinde iyimserliğin çevrimiçi güvenliğin anlamlı bir yordayıcısı olduğu görülmektedir. Çevrimiçi güvenliği yordayan değişkenlere ilişkin doğrusal regresyon analizi sonuçları, iyimserliğin çevrimiçi güvenlik davranışının \% 7,1'ini açıladığını göstermektedir. Sonuç olarak çevrimiçi güvenliğin \% 7,1'inin iyimserlikle açıklandığı söylenebilir.

Tablo 12. Kötümserliğin çevrimiçi güvenlik alt boyutunu yordamasına ilişkin basit doğrusal regresyon analizi sonuçları

\begin{tabular}{lcccccc}
\hline & \multicolumn{2}{c}{ Standardize Edilmemiş Katsayı } & \multicolumn{2}{c}{ Standardize Edilmiş Katsayı } & & \\
\cline { 2 - 5 } Model & $\mathrm{B}$ & Std. Hata & Beta & $\mathrm{t}$ & $\mathrm{p}$ \\
\hline 1 Sabit & 16.21 & .61 & & 26.44 & .00 \\
\hline Kötümserlik & -.05 & .03 & -.10 & -1.94 & .05 \\
\hline
\end{tabular}

$\mathrm{R}^{2}=.007, \mathrm{~F}(1-375)=3.766{ }^{*} \mathrm{p}>.05$

Tablo 12 incelendiğinde kötümserliğin çevrimiçi güvenliğin anlamlı bir yordayıcısı olmadığı görülmektedir. Sonuç olarak kötümserlik çevrimiçi güvenlik davranışını yordamamaktadır. 


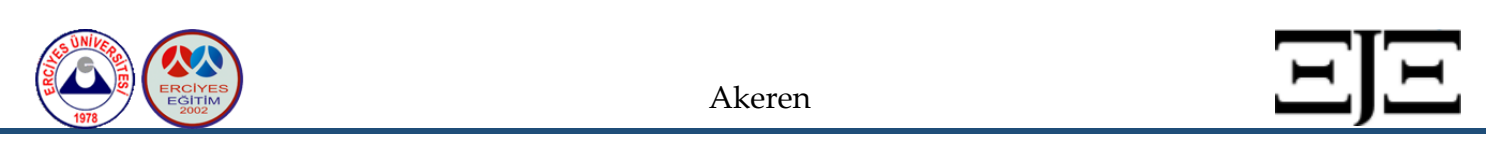

Erciyes Journal of Education 2021, Vol 5, No 1, 87-104

\section{TARTIŞMA, SONUÇ VE ÖNERILER}

$\mathrm{Bu}$ araştırmada ergenlerin iyimserlik ve kötümserlik puanları ile siber zorbalıkla başa çıkma puanlarının ne düzeyde olduğunu, bu iki değişken arasındaki ilişkiyi incelemiştir. Ayrıca ergenlerin iyimserlik-kötümserlik düzeyinin onların siber zorbalıkla başa çıkma becerilerini ne düzeyde yordadığı incelenmiştir. Araştırma, iyimserlik ile siber zorbalıkla başa çıkma arasında pozitif yönde, kötümserlik ile siber zorbalıkla başa çıkma arasında ise negatif yönde ilişki olduğunu ortaya koymuştur. Ayrıca iyimserlik düzeyinin siber zorbalıkla başa çıkmanın tüm boyutlarını yordadığı, kötümserlik düzeyinin siber zorbalıkla başa çıkmanın sosyal destek arama ve yardım arama boyutlarını yordadığı, mücadele etme ve çevrimiçi güvenlik alt boyutlarını ise yordamadığı ortaya çıkmıştır. Ergenlerin iyimserlik düzeyindeki artışın onların siber zorbalıkla başa çıkma becerilerini artırdığı̆, kötümserlik düzeyindeki artışın sosyal destek arama ve yardım arama becerilerini azalttığı, mücadele etme ve çevrimiçi güvenlik becerilerini ise etkilemediği tespit edilmiştir.

İyimserliğin siber zorbalıkla başa çıkmayla pozitif yönlü ilişkili olduğu bulgusu daha önceki ilgili araştırma bulgularıyla tutarlılık göstermektedir (Beebe, 2010; Snyman ve Loh, 2015). İyimserlik, bir kişilik özelliği olarak ele alındığında bireyin genel bir olumlu beklentiye sahip olma derecesidir. Yüksek iyimserliğe sahip olan bireylerin öznel iyi oluşlarının da yüksek olduğu söylenebilir. Bu kişiler büyük engellerle başa çıkar, engeller karşısında daha az kaçınma, pes etme davranışı gösterirler. Ayrıca iyimser bireylerin sosyal ilişkilerinin kötümserlere nazaran daha başarılı olduğu görülmektedir (Carver vd., 2010). Bu özellikleri nedeniyle iyimser bireyler bir çatışma biçimi olan zorbalık karşısında etkili başa çıkma stratejilerini başarılı şekilde kullanabilmektedirler. Nitekim zorbalığa katılmayan ilköğretim ikinci kademe öğrencilerinin iyimserlik düzeylerinin zorbalara ve kurbanlara göre daha yüksek olduğu bildirilmektedir (Totan ve Tabakçı, 2010). Aynı şekilde Betts vd. (2019), ergenlerde, genç yetişkinlerde ve yetişkinlerde iyimserlikle birlikte siber zorbalığın mağduru olma risklerinin düştüğünü bildirmektedirler. Mevcut araştırmayla doğrudan karşılaştırılmasa da Glasø ve Notelaers (2012) iyimserliğin iş yerinde zorbalığa maruz kalma ile iş doyumu arasında aracı rol üstlendiğini bildirmişlerdir. $\mathrm{Bu}$ bulgu iyimserliğin zorbalığın olumsuz etkilerini azalttığını ortaya koymaktadır. Yine doğrudan karşılaştırmasa da bu araştırmanın bulgusuyla tutarlı şekilde Seçer (2014), zorbalığa maruz kalan öğrencilere yönelik uyguladığı bilişsel-davranışçı yaklaşım temelli grupla psikolojik danışma programı sonucunda öğrencilerin iyimserlik düzeylerinin anlamlı düzeyde arttığını ve mağduriyet algılamalarının anlamlı düzeyde azaldığını ortaya koymuştur. Farklı olarak Altan ve Eldeleklioğlu (2019), duygusal zekânın alt boyutu olan iyimserliğin siber zorbalığı yordamadığını belirtmişlerdir.

İyimserliğin diğer ucunda bulunan kötümserliğin siber zorbalıkla başa çıkmanın sosyal destek arama ve yardım arama davranışlarını anlamlı düzeyde azalttığı, mücadele etme ve çevrimiçi güvenlik davranışlarını etkilemediği; genel olarak bakıldığında ise kötümserliğin siber zorbalıkla başa çıkmayı yordadığı söylenebilir. Yapılan literatür taramasında bu bulgunun doğrudan karşılaştırılacağı bir araştırma bulgusuna rastlanmamıştır. Kötümserliğin siber zorbalıkla başa çıkmaya etkisinin görece daha az araştırılması, bu değişkenin dolaylı olarak iyimserlik üzerinden araştırıldığını düşündürmektedir. Başka bir şekilde ifade edilecek olursa iyimserliğin siber zorbalıkla başa çıkmaya etkisinin ortaya konmasının zıddı olan kötümserliğin etkisinin tam aksi 
olduğu yönünde yorumlanabilir. Kötümser bireyler zorluklarla yüzleşmede isteksiz, kaçnan tavra sahip ve onların üstesinden gelme konusunda başarısız kişilerdir, ayrıca çevresinde başvuracağı sosyal kaynakları kısıtlıdır. Kötümser kişiler, düşük öz güvene sahip ve yetenekleri konusunda şüphelidirler (Carver vd., 2010). Bu özelliklerinin onların siber zorbalıkla baş etmede sosyal destek arayışına girmelerine ve yardım talep etmelerine engel oluşturduğu söylenebilir. Kötümserliğin siber zorbalığa karşı mücadele etmeye ve çevrim içi güvenliğe etkisinin olmaması ise bu öğrencilerin sahip oldukları özellik nedeniyle isteksizlik-eylemsizlik durumuyla açıklanabilir. Çünkü kötümserler sorunlar karşısında hiçbir şeyi değiştiremeyecekleri yönünde bir yaklaşım tarzına sahiptir (Goleman, 2016). Öte yandan Carver vd. (2010), toplumda kötümserlerin iyimserlere göre daha az olduğunu, ayrıca kötümserler hakkında iyimserlere göre daha az bilgiye sahip olduğumuzu belirtmektedirler. Bu açılama, siber zorbalıkla başa çıkmayı açılamada kötümserliğin iyimserliğe göre neden zayıf olduğu konusunda fikir verdiği söylenebilir. Meland vd. (2010), 11-15 yaş aralığında bulunan zorba ve mağdurlar üzerinde yaptıkları araştırmada zorbaların ve mağdurların zorbalıkla ilgisi olmayan öğrencilere kıyasla daha fazla duygusal bozukluk, bedensel şikâyet, özgüven eksikliği ve kötümserlik bildirdikleri sonucuna ulaşmışlardır. Benzer şekilde zorbalık mağdurlarının kendilerini daha yalnız ve kötü hissettikleri belirtilmektedir (Nansel vd., 2001). Bu bilgiler ışığında bu araştırmanın kötümserlik düzeyi yüksek olan öğrencilerin mücadele etme ve çevrimiçi güvenlik davranışlarını yordamadığı bulgusu, kötümserliğin zorbalığa maruz kalmanın sebebi olmanın yanı sıra zorbalığın sonucu da olabileceği düşüncesini doğurmaktadır. Nitekim Navarro vd. (2015), siber zorbalık mağdurlarının iyimserlik puanlarının düştüğünü bildirmektedir. Van Dyk ve Nelson (2013) ise 8-11 yaş arasındaki çocuklar üzerinde yapmış oldukları araştırmanın sonuçlarına dayanarak kötümserliğin zorbalık mağduriyetini artırdığını belirtmektedirler.

İyimserliğin siber zorbalıkla başa çıkmanın tüm alt boyutlarını olumlu yönde güçlü bir şekilde yordaması, kötümserliğin siber zorbalıkla başa çıkmanın sosyal destek arama ve yardım aramayı negatif yönde yordaması, siber zorbalıkla mücadelede göz önünde bulundurulmalıdır. Çünkü siber zorbalığın mağduru olmak öğrencilerin öznel iyi oluşlarını olumsuz etkilemektedir. Bu amaçla okul rehberlik servislerinin siber zorbalıkla mücadele programlarında öğrencilerin bilhassa iyimserlik düzeylerini artıracak etkinlik ve uygulamalara yer vermeleri önerilebilir. Çünkü siber zorbalıkla etkili başa çıkma becerilerinin öğrenilmesi ve kullanılması bu yıkıcı davranışın öğrencilerin iyilik halleri üzerindeki olumsuz etkisini azaltacaktır. Ayrıca siber zorbalığın mağduru olan öğrencilerin iyimserlik düzeylerinin düşük, kötümserlik düzeylerinin yüksek olduğu söylenebilir (Niu vd., 2018). Bu nedenle söz konusu öğrencilerin yaşadıkları mağduriyetin üstesinden gelebilmelerinde bu değişkenlerin dikkate alınmasında yarar görülmektedir. Kötümserlik düzeyi yüksek öğrencilerin siber zorbalık riski altında olduğunun göz önünde bulundurulması gerekmektedir. Öte yandan öğrencilerdeki kötümserlik düzeyinin yüksek olmasında siber zorbalığın mağduru olmalarından da kaynaklanabileceği göz önünde bulundurulmalıdır. Bu şekilde düşünüldüğünde kötümserliğin siber zorbalıkla başa çıkmada etkisiz davranışlara neden olmasının yanı sıra kötümserliğin siber zorbalığın sonucu olabileceği de dikkate alınmalıdır. Özetle kötümser öğrencilerin siber zorbalığa maruz kalmış olma ihtimalleri de dikkate alınarak ilgili eğitim programına dâhil edilmeleri önerilebilir. İyimser bireylerin siber zorbalıkla başa çıkmada daha etkili davranışlar sergilemelerinin yanında bu bireylerin siber zorbalığa maruz kaldıklarında bunun olumsuz etkilerini daha az yaşadıkları da 
bildirilmektedir (Rey vd., 2020). Bu durum iyimserlerin siber zorbalık gibi olumsuz bir olayla başa çıkarken olumlu anlamlar aramasıyla ilgilidir.

Araştırma bulgularınızı ilgili alanyazın çerçevesinde tartışınız. Sonuç ve önerilerinizi buraya yazınız. Araştırma bulgularınızı ilgili alanyazın çerçevesinde tartışınız. Sonuç ve önerilerinizi buraya yazınız. Araştırma bulgularınızı ilgili alanyazın çerçevesinde tartışınız. Sonuç ve önerilerinizi buraya yazınız. Sonuç ve önerilerinizi buraya yazınız. Araştırma bulgularınızı ilgili alanyazın çerçevesinde tartışınız. Sonuç ve önerilerinizi buraya yazınız. Araştırma bulgularınızı ilgili alanyazın çerçevesinde tartışınız.

\section{KAYNAKÇA / REFERENCES}

Akcan, S. (2010). Sosyal bilgiler öğretiminde okul dışı çevre eğitimi unsurları (Bilecik ili örneği) (Yayınlanmamış Yüksek Lisans Tezi). Abant İzzet Baysal Üniversitesi. Bolu.

Akbaba, S. ve Eroğlu, Y. (2013). İlköğretim öğrencilerinde siber zorbalık ve mağduriyetin yordayıcıları. Uludağ Üniversitesi Ĕ̆itim Fakültesi Dergisi, 26(1), 105-121.

Akbıyık, C. ve Kestel, M. (2016). Siber zorbalığın öğrencilerin akademik, sosyal ve duygusal durumları üzerindeki etkisinin incelenmesi.Mersin Üniversitesi Ĕ̆itim Fakültesi Dergisi, 12(3), 844-859.

Altan, T. ve Eldeleklioğlu, J. (2019). Lise öğrencilerinde siber zorbalığın yordayıcısı olarak siber mağduriyet ve duygusal zekâ. Elementary Education Online, 18(4), 2147-2156.

Beebe, J. E. (2010). The Prevalence of Cyber Bullying Victimization and Its Relationship to Academic, Social, and Emotional Adjustment among College Students. ProQuest LLC. 789 East Eisenhower Parkway, PO Box 1346, AnnArbor, MI 48106.

Belsey, B. (2007). Cyberbullying: A real and growing threat. ATA Magazine, 88(1), 14-21.

Beran, T. and Li, Q. (2005). Cyber-harassment: A study of a new method for an old behavior. Journal of educational computing research, 32(3), 265-277.

Betts, L. R., Metwally, S. H. and Gardner, S. E. (2019). We ares afe but you are not: Exploring comparative optimism and cyberbullying. Journal of Technology in Behavioral Science, 4(3), 227-233.

Carver, C., Scheirer, M. F. and Segerstorm, S. C. (2010). Optimism. Clinical Psychology Review, 30 (7), 879-889.

Çalışkan, H. ve Uzunkol, E. (2018). Ergenlerde iyimserlik-kötümserlik ölçeğinin geliştirilmesi: Geçerlilik ve güvenirlik çalışması. The Journal of Happiness \& Well-Being, 6(2), 78-95.

Edwards, L., Kontostathis, A. E. and Fisher, C. (2016). Cyberbullying, race/ethnicity and mental health outcomes: A review of the literature. Media and Communication, 4(3), 71-78.

Eryılmaz, A. (2013). Pozitif psikolojinin psikolojik danışmanlık ve rehberlik alanında gelişimsel ve önleyici hizmetler bağlamında kullanılması. The Journal of Happiness $\mathcal{E}$ WellBeing, 1(1), 1-22.

Fraenkel, J. R. and Wallen, N. E. (1993). How to design and evaluate research in education. McGrawHill.

Glasø, L. and Notelaers, G. (2012). Work place bullying, emotions, and outcomes. Violence and victims, 27(3), 360-377.

Goleman, D. (2016). Duygusal zekâ: Neden IQ'dan daha önemlidir. (Banu Seçkin Yüksel, Çev.). Varlık Yayınları.

Gürbüz, S. ve Şahin, F. (2017). Sosyal Bilimlerde Araştırma Yöntemleri. Seçkin Yayıncılık. 
Keldal, G. (2015). Warwick-Edinburgh mental iyi oluş ölçeği'nin Türkçe formu: Geçerlik ve güvenirlik çalışması. The Journal of Happiness \& Well-Being, 3(1), 103-115.

Koç, M., Horzum, M. B., Ayas, T., Aydın, F., Özbay, A. ve Uğur, E. (2016). Sanal zorbalıkla baş etme ölçeği: Geçerlilik ve güvenirlik çalışması. Sakarya University Journal of Education, 6(3), 116-128.

Kokkinos, C. M., Antoniadou, N. and Markos, A. (2014). Cyber-bullying: An investigation of the psychological profile of university student participants. Journal of Applied Developmental Psychology, 35(3), 204-214.

Kutlu, M., Balcı, S. ve Yılmaz, M. (2004). İletişim beceri eğitiminin öğrencilerin kendini ayarlama ve iyimserlik düzeylerine etkisi. XIII. Ulusal Eğitim Bilimleri Kurultayı, 6-9.

Meland, E., Rydning, J. H., Lobben, S., Breidablik, H. J. and Ekeland, T. J. (2010). Emotional, selfconceptual, and relational characteristics of bullies and the bullied. Scandinavian Journal of Public Health, 38(4), 359-367.

Mitchell, K. J., Ybarra, M. and Finkelhor, D. (2007). The relative importance of online victimization in understanding depression, delinquency, and substanceuse. Child Maltreatment, 12(4), 314-324.

Nansel, T. R., Overpeck, M., Pilla, R. S., Ruan, W. J., Simons-Morton, B. and Scheidt, P. (2001). Bullying behaviors among US youth: Prevalence and association with psychosocial adjustment. Jama, 285(16), 2094-2100.

Navarro, R., Ruiz-Oliva, R., Larrañaga, E., and Yubero, S. (2015). The impact of cyberbullying and social bullying on optimism, global and school-related happiness and life satisfaction among 10-12-year-old school children. Applied Research in Quality of Life, 10(1), 15-36.

Niu, G. F., Zhou, Z. K., Sun, X. J., Yu, F., Xie, X. C., Liu, Q. Q., and Lian, S. L. (2018). Cyberostracism and its relation to depression among Chinese adolescents: The moderating role of optimism. Personality and Individual Differences, 123, 105-109.

Olenik-Shemesh, D. and Heiman, T. (2014). Exploring cyberbullying among primary children in relation to social support, loneliness, self-efficacy, andwell-being. Child Welfare, 93(5), 27.

Olenik-Shemesh, D. and Heiman, T. (2017). Cyberbullying victimization in adolescents as related to body esteem, social support, and social self-efficacy. TheJournal of Genetic Psychology, 178(1), 28-43.

Peker, A., Özhan, M. B. ve Eroğlu, Y. (2015). Ergenlere yönelik siber zorbalıkla başa çıkma ölçeği'nin geliştirilmesi. International Journal of Human Sciences, 12(1), 569-581. 10.14687/ijhs.v12i1.3156

Peterson, C. (2000). The future of optimism. American psychologist, 55(1), 44-55.

Rey, L., Quintana-Orts, C., Mérida-López, S., and Extremera, N. (2020). The Relationship between Personal Resources and Depression in a Sample of Victims of Cyberbullying: Comparison of Groups with and without Symptoms of Depression. International Journal of Environmental Research and Public Health, 17(24), 9307.

Scherer, K. R., Schorr, A. and Johnstone, T. (Eds.). (2001). Appraisal processes in emotion: Theory, methods, research. Oxford University Press.

Seçer, İ. (2014). Akran zorbalı̆̆ına uğrayan ergenlerin mağduriyet algılamaları ve kullandıkları başa çıkma stratejilerine grupla psikolojik danışmanın etkisinin incelenmesi. (Doktora Tezi). Atatürk Üniversitesi, Erzurum.

Seligman, M. E. P. (2007). Öğrenilmiş iyimserlik, (S. Kunt Akbaş, Çev.). Hekimler Yayın Birliği.

Sheldon, K. M. and King, L. (2001). Why positive psychology is necessary. American psychologist, 56(3), 216. 
Smith, P. K., Mahdavi, J., Carvalho, M., Fisher, S., Russell, S. and Tippett, N. (2008). Cyberbullying: Its nature and impact in secondary school pupils. Journal of child psychology and psychiatry, 49(4), 376-385.

Snyman, R. and Loh, J. M. (2015). Cyberbullying at work: The mediating role of optimism between cyberbullying and job outcomes. Computers in Human Behavior, 53, 161-168.

Tabachnick, B. G., Fidell, L. S. and Ullman, J. B. (2007). Using multivariate statistics. (5th ed. 481498). Boston, MA: Pearson.

Temel, E., Bahar, A. ve Çuhadar, D. (2007). Öğrenci hemşirelerin stresle baş etme tarzları ve depresyon düzeylerinin belirlenmesi. Fırat Sağlık Hizmetleri Dergisi, 2(5), 107-118.

Totan, T. ve Kabakçı, Ö. F. (2010). İlköğretim ikinci kademe öğrencilerinde sosyal duygusal öğrenme becerilerinin zorbalığı yordama gücü. Uludă̆ Üniversitesi Eğitim Fakültesi Dergisi, 23(2), 575-600.

Van Dyk, Tori R. and Nelson, Timothy D. (2014). Peer victimization and child physical health: The moderating role of pessimism. Journal of Pediatric Psychology 39(4), 469-480.

Völlink, T.,Bolman, C. A., Dehue, F. and Jacobs, N. C. (2013). Coping with cyberbullying: Differences between victims, bully-victims and children not involved in bullying. Journal of Community \& AppliedSocial Ppsychology, 23(1), 7-24.

Wolak, J., Mitchell, K. J. and Finkelhor, D. (2006). Online victimization of youth: Five years later. National Center for Missing \& Exploited Children Bulletin - \#07-06-025. Alexandria, VA. 